\title{
The Microbial Burden Load of Eggshells from Different Poultry Rearing Systems in Ekosodin Village, Edo State, Nigeria
}

\author{
*1OVIASOGIE, F. EFOSA, ${ }^{2}$ OGBOGHODO, I. BLESSING, ${ }^{3}$ BESHIRU, A., \\ ${ }^{4}$ OMOREGIE, B. OSAHON, ${ }^{5}$ OGOFURE PROVIDENCE ${ }^{6}$ OGOFURE, A. \\ GOODNESS,
}

\author{
Department of Microbiology, Faculty of Life Sciences, University of Benin \\ Corresponding author: Ogofure A. Goodness, Telephone: 08100490847 \\ Email address: abraham.ogofure@uniben.edu
}

\begin{abstract}
Eggs are valuable source of food used throughout the world to feed the ever growing world population. Majority of freshly laid eggs are sterile, however, the shells soon become contaminated with litter droppings and dust present in the environment. In this study, the microbial load of egg shell from different poultry system in Ekosodin, Edo State was evaluated. The results obtained from the study revealed that eggshell samples from different poultry rearing systems (battery cage, deep litter and free-range chicken eggs) were contaminated with bacterial and fungal species of public health concern. Microbial species isolated from eggshells were Enterobacter aerogenes, Escherichia coli, Citrobacter freundii, Bacillus cereus, Enteroccocus faecalis and Proteus mirabillis for the bacterial isolates while the fungi isolates include Mucor sp., Rhizopus sp., Aspergillus sp., Fusarium sp. and Penicillium sp. The bacterial and fungal load of free-range chicken eggshell ranged from $9.7 \pm 0.7 \times 10^{4}$ to $1.27 \pm 0.2 \times 10^{5}$ and $7.0 \pm 0.5 \times 10^{3}$ to $2.2 \pm 0.5 \times 10^{4} \mathrm{cfu} / \mathrm{g}$ respectively. Bacterial and fungal counts were $3.3 \pm 0.8 \times 10^{4}$ to $7.4 \pm 0.5 \times 10^{4}$ and $1.1 \pm 0.1 \times 10^{4}$ to $1.6 \pm 0.4 \times 10^{4} \mathrm{cfu} / \mathrm{g}$ for battery cage eggshells and $6.8 \pm 0.9 \times 10^{4}$ to $1.38 \pm 0.5 \times 10^{5}$ and $2.0 \pm 0.3 \times 10^{4}$ to $3.7 \pm 0.5 \times 10^{4} \mathrm{cfu} / \mathrm{g}$ for deep litter eggshells respectively. Statistically, the mean fungi count of deep litter egg shells samples differed significantly $(\mathrm{P}<0.05)$ from the mean fungal count of battery cage and free-range chicken eggshells. Also, the mean bacterial count of battery cage egg shells differed significantly from deep litter and free-range chicken eggshells $(\mathrm{P}<0.05)$. The presence of these microorganisms on eggshell might constitute a serious risk to consumers. Proper education to enlighten retailers and consumers by the government on microbial quality of table eggs is important. Proper sanitation and battery cage system of rearing eggs should be encouraged. ( ) JASEM
\end{abstract}

\section{http://dx.doi.org/10.4314/jasem.v20i2.1}

KEY WORDS: Deep litter system, battery cage system, eggshell microbial load, microbial quality of table eggs.

Food of animal origin such as meat and eggs are implicated as the most common cause of food-borne infection. Eggs are often rinsed with alkaline detergents and chlorine solutions to reduce microbial load on the shell (Bialka et al., 2004). In developed countries like the United States, Canada and Japan, microbial load of table eggs are routinely evaluated before retailing (Arathy et al., 2009). This practice is not quite common in developing countries especially those in sub-sahara Africa. In certain countries, bacteria isolated from table eggs were linked to some human illness. In a pilot study conducted in Grenada with 160 table eggs, majority of the bacteria isolated belong to Enterobacteriaceae group (Arathy et al., 2009). Increasing consumer awareness about food safety issues has changed the public perception of a good egg from its shell cleanliness and physical properties to that of microbial integrity. Microbial contaminations of eggs usually occur few seconds after production, through processing, preparation up till consumption (Indhu et al., 2014). Freshly laid eggs are generally devoid of microorganisms. However, following exposure to environmental conditions (for example, soil, dust and dirty nesting materials), eggs become contaminated with different types of microorganisms (Abdul et al., 2012). Eggs can fully meet the requirements of all nutrients necessary for human development and life functions. At the same time, many nutrient substances present in egg create an excellent environment for the development of different microflora, including pathogenic microorganisms (Jehan et al., 2014).

These microorganisms may contaminate the egg's contents either by penetration or withdrawal through pores of the shells (Abdul et al., 2012). Reducing microbial contamination of eggshells may help to decrease the incidence of bacterial infections in 
developing embryos and newly hatched chicks. Microorganisms can penetrate the eggshell through shell pores or cracks and can kill the developing embryo, reduce hatchability, and negatively affect the chick post-hatching (Fasenko et al., 2009). Hatched chicks can also be infected through contact with contaminated eggshells and hatchery equipment (Cason et al., 1994), with infected chicks then transmitting bacteria such as Salmonella enterica serovar Enteritidis, pathogenic Escherichia coli, and Listeria monocytogenes to other chicks in the growing flock (Fasenko et al., 2009). Numerous studies have evaluated the bacterial contamination of shell eggs during production and processing by sampling eggs, equipment, feed and the hens' reproduction tracts (Northcutt et al., 2004). Jones et al. (1995) found Salmonella in $72 \%$ of the environmental samples collected from hen houses, $7.8 \%$ of egg shells before washing and $1.1 \%$ of egg shells after washing. However, Salmonella was not found in the contents of any of the egg samples evaluated.

Knape et al. (2002) reported that the aerobic plate counts from egg rinses decreased by 2.9 and $1.5 \mathrm{log}$ $\mathrm{cfu} / \mathrm{ml}$ for in-line and off-line eggs, respectively when counts on eggs at the transfer belt were compared with counts on eggs after washing. Board et al. (1964) evaluated the microbiological contamination of egg shells and egg packaging materials and postulated that unpacking dirty eggs from flats created aerosols that could result in product contamination. Understanding which factor drives microbial communities on eggshells may lead to a better comprehension of evolutionary strategies that improve embryo survival. Environmental components, parental physiology and behavior, and their interactions, are key drivers of these microbial communities (Ruiz-de-Castañeda et al. 2011a). Parental incubation behavior has been found to reduce or limit bacterial growth on the eggshell surface and also decrease bacterial and fungal invasion of egg contents by limiting trans-shell infection, when compared with eggs that are left exposed (and unincubated) (Gizzard et al., 2014). Environmental components such as protection against adverse conditions, nest structure, reuse of a nest, and choice of lining materials (such as the feathers) can influence bacterial loads on eggshells (Baggott and Graeme-Cook 2002; Peralta-Sanchez et al. 2010; Walls et al. 2012).

However there is dearth of scientific information on fungal contamination of egg-shell, despite their presence in the nest environment (Goodenough and Stallwood 2012). Fungi might play an active role in microbial invasion as their hyphae can penetrate the eggshell leading to an increase in the number of unplugged pores, which can be used by pathogenic bacteria as a direct route to egg contents (Board and Tranter 1995). Fungal metabolites such as aflatoxins can contaminate a vast array of foods and agriculture commodities. The possible transmission of such toxic residues to edible eggs results in potential hazards to human health (Abdul et al., 2012). Aflatoxins are known to be human carcinogens based on sufficient evidence of carcinogenicity in humans (Abdul et al., 2012). Periodical assessment is required to offer safe and good quality eggs for consumption because of the continuous consumer demand for eggs worldwide. The present investigation was, therefore, planned to assess shell quality of consumed eggs in Ekosodin village located in Ovia North, Benin City, Edo State. The Microbiological quality and presence of foodborne pathogens were evaluated.

\section{MATERIALS AND METHODS}

Collection of Samples: A total of 200 egg samples were collected from four poultry farms in Ekosodin village. The egg samples were placed in a sterile polythene bag and transferred to the laboratory without delay and prepared for microbiological analysis. The collected eggs were classified into three groups: free-range chicken eggs (NE), eggs from battery cage system (BC) and eggs from deep litter system (DL).

Sterilization of Materials: Glass wares such as petri dishes, test tubes, glass rod, pipette measuring cylinder beakers and conical flasks required for the investigation were soaked and washed in detergent and rinsed with distilled water. They were wrapped in aluminum foil paper and dried in the oven in an inverted position at $160^{\circ} \mathrm{C}-170^{\circ} \mathrm{C}$ for $45-60 \mathrm{~min}$. All the glass wares used were products of Pyrex $^{\circledR}$ in England.

Preparation and Enumeration of Samples of Egg Shells: The eggs from poultry were soaked in $100 \mathrm{ml}$ normal saline solution in a sterile beaker. Subsequently the content was shaken gently and allowed to stand for 10 minutes. Ten (10) fold serial dilution was prepared from the normal saline solution for enumeration of bacterial isolates. The process was repeated three times. A pour plate technique was performed using appropriate dilutions in nutrient agar and potato dextrose agar. The Nutrient plates were incubated at $37{ }^{\circ} \mathrm{C}$ for $24-48$ hours. Fungal enumeration was determined using potato dextrose agar with $0.5 \mathrm{ml}$ of antibacterial agent incorporated. The antibacterial agent was prepared by dissolving $1.0 \mathrm{~g}$ of Streptomycin in $30.0 \mathrm{ml}$ sterilized distilled

${ }^{* 1}$ Oviasogie, F. Efosa, ${ }^{2}$ Ogboghodo, I. Blessing, ${ }^{3}$ Beshiru, A., ${ }^{4}$ Omoregie, B. Osahon, ${ }^{5}$ Ogofure Providence

${ }^{6}$ Ogofure, A. Goodness, 
water. The plates were incubated at room temperature $\left(28 \pm 2^{\circ} \mathrm{C}\right)$ for fungal colonies to develop. The microbial counts were expressed as number of $\mathrm{cfu} / \mathrm{g}$ egg material. Identification of bacterial and fungal isolates were carried out by methods delineated by Cheesbrough (2000) and Barnet and Hunter (1995) respectively.

Statistical Analysis: All data in the study were analysed using the statistical package SPSS version 21.0. Values in triplicates were analysed using measures of central tendency (mean \pm standard deviation). One-Way ANOVA was used to compare multiple variables while Duncan multiple range test was used to check for significant difference between

Table 1. Bacterial and fungal count of eggs obtained from deep litter poultry system

\begin{tabular}{ccc}
\hline Poultry & Bacterial count & \multicolumn{1}{c}{ Fungal count } \\
\hline A & $1.12 \pm 0.5 \times 10^{5}$ & $2.7 \pm 0.9 \times 10^{4}$ \\
$\mathrm{~B}$ & & Legend: \\
$\mathrm{C}$ & 1 & Values are mean \pm S.E of triplicate determination \\
$\mathrm{D}$ & 1 & A-D different poultry for sample collection \\
Legend: Values $~$ &
\end{tabular}

mean. $P$-values less than 0.05 were considered statistically significant.

\section{RESULTS AND DISCUSSION}

Results obtained from this study showed that eggshell Results obtained from this study showed that eggshell samples from different rearing systems (battery cage, deep litter and free-range chicken eggs) were contaminated with bacteria. The bacterial and fungal count of free-range chicken egg shell ranged between $9.7 \pm 0.7 \times 10^{4}$ to $1.27 \pm 0.2 \times 10^{5}$ and $7.0 \pm 0.5 \times 10^{3}$ to $2.2 \pm 0.5 \times 10^{4} \mathrm{cfu} / \mathrm{g}$.

Table 2. Bacterial and fungal count of eggs obtained from battery cage system

\begin{tabular}{ccc}
\hline Poultry & Bacterial count & Fungal count \\
\hline A & $7.4 \pm 0.5 \times 10^{4}$ & $1.3 \pm 0.2 \times 10^{4}$ \\
B & $5.1 \pm 0.9 \times 10^{4}$ & $1.1 \pm 0.1 \times 10^{4}$ \\
C & $5.3 \pm 1.8 \times 10^{4}$ & $1.1 \pm 0.5 \times 10^{4}$ \\
D & $3.3 \pm 0.8 \times 10^{4}$ & $1.6 \pm 0.4 \times 10^{4}$ \\
\hline
\end{tabular}

Table 3 Bacterial and fungal count of eggs laid by free-range chicken hens

\begin{tabular}{ccc}
\hline Poultry & Bacterial count & Fungal count \\
\hline A & $1.27 \pm 0.2 \times 10^{5}$ & $2.2 \pm 0.5 \times 10^{4}$ \\
B & $1.25 \pm 0.1 \times 10^{5}$ & $1.4 \pm 0.3 \times 10^{4}$ \\
C & $1.17 \pm 0.5 \times 10^{5}$ & $1.9 \pm 0.2 \times 10^{4}$ \\
D & $9.7 \pm 0.7 \times 10^{4}$ & $7.0 \pm 0.5 \times 10^{3}$ \\
\hline
\end{tabular}

Table 4. Cultural morphological and biochemical characteristics of bacterial isolates

\begin{tabular}{|c|c|c|c|c|c|c|}
\hline Characteristics & $\mathrm{B} 1$ & $\mathrm{~B} 2$ & B3 & B4 & B5 & B6 \\
\hline \multicolumn{7}{|l|}{ Cultural } \\
\hline Elevation & Low convex & Low convex & Low convex & Convex & Convex & Flat \\
\hline Margin & Entire & Entire & Entire & Smooth & Smooth & Serrated \\
\hline Colour & Cream & Cream & Cream & White & White & Cream \\
\hline Shape & Circular & Circular & Circular & Circular & Circular & Circular \\
\hline \multicolumn{7}{|l|}{ Morphological } \\
\hline Gram stain & - & - & - & + & + & - \\
\hline Spore stain & - & - & - & + & - & - \\
\hline Cell type & Rod & Rod & Rod & Rod & Cocci & Rod \\
\hline Cell arrangement & Single & Single & Single & Single & Single & Single \\
\hline \multicolumn{7}{|l|}{ Biochemical } \\
\hline Catalase & + & + & + & + & - & + \\
\hline Indole & - & + & - & - & - & - \\
\hline Urease & + & - & - & - & + & + \\
\hline Oxidase & - & - & - & - & - & - \\
\hline Coagulase & - & - & - & - & - & - \\
\hline Citrate & + & - & + & - & - & + \\
\hline Glucose & + & + & + & + & + & + \\
\hline
\end{tabular}

Legend: $\mathrm{B} 1=$ Enterobacter aerogenes; $\mathrm{B} 2=$ Escherichia coli $; \mathrm{B} 3=$ Citrobacter freundii; $\mathrm{B} 4=$ Bacillus cereus; B5= Enterococcus faecalis; $\mathrm{B} 6=$ Proteus mirabilis

Table 5. Cultural and morphological characteristics of the fungal isolates

${ }^{* 1}$ Oviasogie, F. Efosa, ${ }^{2}$ Ogboghodo, I. Blessing, ${ }^{3}$ Beshiru, A., ${ }^{4}$ Omoregie, B. Osahon, ${ }^{5}$ Ogofure Providence

${ }^{6}$ Ogofure, A. Goodness, 


\begin{tabular}{|c|c|c|c|c|c|}
\hline Characteristics & F1 & F2 & F3 & F4 & F5 \\
\hline $\begin{array}{l}\text { Cultural } \\
\text { Morphological }\end{array}$ & Cotton white & Dark black & Green & Cotton white & Cotton white \\
\hline Hyphae type & Non-septate & Septate & Septate & Septate & Septate \\
\hline Spores formed & Sporangiophore & Conidiophores & Conidiophores & Conidiophores & Chlamydophore \\
\hline Colour of spore & Brownish & Brownish & Greenish & Whitish & Whitish \\
\hline Rhizoid & Present & Absent & Absent & Absent & Absent \\
\hline Stolon & Present & Absent & Absent & Absent & Absent \\
\hline
\end{tabular}

Egg is the hard-shelled reproductive body produced by a bird, especially by the common domestic chicken and its contents used as food throughout the world. Although, the majority of freshly laid eggs are sterile, the shells soon become contaminated with litter droppings, dust and prevailing environment. In this study, bacterial and fungal count of eggs obtained from deep litter poultry system, battery cage poultry system and free-range chicken system were evaluated. Furthermore, cultural and morphological characteristics of the fungal isolates and cultural morphological and biochemical characteristics of bacterial isolates were also assessed. Freshly laid eggs are usually very sterile. Numerous microorganisms may be found on the surface within a relatively short time and under certain conditions may penetrate into the eggs and grow to cause spoilage (Smith et al., 2000). The result of this study is in accordance with the result of previous studies by Ahmed et al. (2002), Zahran (2003) and Suba et al. (2005) who reported that similar bacterial and fungal species were isolated from egg shells. It is evident from the microbial count in this study that the highest colony counts for bacterial and fungal species from the different egg shell samples are in eggs from deep litter system $\left(1.38 \pm 0.5 \times 10^{4}\right)$ closely followed by free-range chicken egg shell sample $\left(1.27 \pm 0.2 \times 10^{5}\right.$ and $\left.2.2 \pm 0.5 \times 10^{4}\right)$. The least microbial count $\left(7.4 \pm 0.5 \times 10^{4}\right.$ and $\left.1.6 \pm 0.4 \times 10^{4}\right)$ was obtained from battery cage system. Statistically, the mean fungi count of deep litter egg shells samples differed significantly $(\mathrm{P}<0.05)$ from the mean fungal count of battery cage and free-range chicken egg shells. Also, the mean bacterial count of battery cage egg shells differed significantly from deep litter and free-range chicken egg shells. The low microbial count recorded in the battery cage system is due probably to a better method of egg collection in terms hygiene (Board et al. 1964). On the other hand, the high microbial counts of free-range chicken and deep litter egg shell samples indicates poor hygienic conditions under which the eggs were laid, handled and stored. Numerous studies have been conducted to evaluate the bacterial contamination of shell eggs during production and processing by sampling eggs, equipment, feed and the hens' reproductive tracts (Hara-Kudo et al., 2001; Knape et al., 2002; Davies and Breslin, 2003; Jones et al., 2003). The most important route of contamination of the egg shells with microorganisms is the fecal route. Immediately after the eggs are laid, or at later stages, there is this chance that the eggs become contaminated with fecal material. The microorganism found in the fecal material may penetrate the shell and the membrane due to the vacuum-effect resulting from the loss of heat after the lay, or as a result of unfavorable storage conditions and time, and may reach the egg content (Keller et al., 1995.). This may lead to serious health risk $\mathrm{s}$ when these eggs are consumed raw or uncooked, or when food products containing these eggs are ingested.

Conclusion: The results of this study showed that the different egg shells from the various rearing system examined were contaminated with bacteria and fungi. The microorganisms isolated from the eggshells were Enterobacter aerogenes, Escherichia coli, Citrobacter freundii, Bacillus cereus, Enteroccocus faecalis and Proteus mirabillis for the bacterial isolates while the fungi isolates were Mucor sp., Rhizopus sp., Aspergillus sp., Fusarium sp. and Penicillium sp. The presence of these microorganisms might constitute a serious risk to consumers especially when they are not properly washed before cooking.

\section{REFERENCES}

Abdul, ASB; Sabry, AH; Baling, AE (2012). Microbial Quality and Content Aflatoxins of Commercially Available Eggs in Taif, Saudi Arabia, Afric. J. Micro. Res. 6(13): 33373342.

Ahmed, HF; Azza, M; Deeb, M; Aman, IM (2002). Studies on Market Hen Eggs in Kafr ElSheikh and El- Gharbia Governorates. Vet. Med. J. 50(4):610-615.

Arathy, S; Vanpee, G; Belot, G; Vanessa, M; Claude, D; Ravindra, NS (2009). Bacterial Contamination of Commercial Chicken Eggs in Canada, West Indies. West Ind. Vet. J. 9(2):4-7.

Board, RG; Fuller, R (1994). Microbiology of the Avian Egg ( $4^{\text {th }}$ ed). London Press, London. 897 pp 
Board, RG; Ayres, JC; Kraft, AA; Forsythe, RH (1964). The Microbiological Contamination of Eggshells and Egg Packing Materials. Poultry Sci. 43:584-595.

Davies, RJ; Breslin, M (2003). Investigation of Salmonella Contamination and Disinfection of Farm Egg-packing, J. Appl. Micro. 94:191-196.

Fasenko, GM; Christopher, EEO; MuMullen, LM (2009). Spraying Hatching Eggs with Electrolyzed Oxidizing Water Reduces Eggshell Microbial Load Without Compromising Broiler Production Parameters. Poultry Sci. 88: 1121-1127.

Gizzard, S; Dini-Andreote, F; Tieleman, I; Salles, JF (2014). Dynamics of Bacterial and Fungal Communities Associated with Eggshells During Incubation. In: Ecology and Evolution. John Wiley and Sons Limited 189pp.

Hara-Kudo, Y; Sakakibara, Y; Konuma, H; Sawada, T; Kumagai, S (2001). Laying Season and Eggshell Cracks on the Growth of Salmonella enteritids in the Egg Albumen During Storage. J. Food Prot. 64: 1134-1137.

Indhu, B; Muthusami, S; Thirunavukkarasu, N. (2014). Studies on Microflora and their Role on Eggshell Contamination and Infection. Int. J. Pharm. Chem. Bio. Sci. 4(3): 518-521.

Jehan, II; Dalia, MH; Hosny, AA (2014). Prevalence and Inhibition of Microbial Load on Chicken Eggs with Special Reference to Egg Quality and Hatchability. Am. J. Animal Vet. Sci. 9(4): 294-302.

Jones, D. R., Northcutt, J. K., Musgrove, M. T., Curtis, P. A., Anderson, K. E., Fletcher, D. L. and Cox, N. A (2003). Survey of shell egg processing plant sanitation programs: Effects on egg contact surfaces, Journal of Food Protection 66;1486-1489.

Jones, FT; Rives, DV; Carey, KB (1995). Salmonella Contamination in Commercial Eggs and an Egg Production Facility. Poultry Sci. 74: 753-757.

Keller, LH; Benson, CE; Krotec, K; Eckroade, RJ (1995). Microorganisms Colonization of the Reproductive Tract of Forming and Freshly Laid Eggs of Chicken. Infect. Immunity 63(7): 2443-2449.

Knape, KD; Chaves, C; Burgess, RP; Coufal, SD; Carey, JB (2002). Comparison of Eggshell Surface Microbial Populations for In-line and Offline Commercial Egg Processing Facilities. Poultry Sci. 81: 695-698.

Northcutt, JK; Jones, DR; Ingram, KD; Hinton, A; Musgrove, MT (2004). Airborne Microorganisms on Commercial Shell Egg Processing Facilities. Int. J. Poultry Sci. 3(3): 195-200.

Smith, A; Rose, SP; Wells, RG; Pirgozliev, V. (2000). The Effect of Changing the Excreta Moisture of Caged Laying Hens on the Excreta and the Microbial Contamination of their Eggshells. Brit Poultry Sci. 41: 168-173.

Suba, S; Narahari, D; Prabhakar, TG (2005). Microbial Quality and Safety of Table Eggs Marketed in Commercial Channels. Sixteenth European Symposium on the Quality of Egg and Egg Production 7: 23-26.

Zahran, SE (2003). Quality Assessment of Table Eggs. Ph.D. Thesis Faculty of Veterinary Medicine, Tanta University. 214pp.

\footnotetext{
${ }^{*}$ Oviasogie, F. Efosa, ${ }^{2}$ Ogboghodo, I. Blessing, ${ }^{3}$ Beshiru, A., ${ }^{4}$ Omoregie, B. Osahon, ${ }^{5}$ Ogofure Providence

${ }^{6}$ Ogofure, A. Goodness,
} 